\title{
PENGARUH PEMBELAJARAN STEAM (Science, Technology, Engineering, Arts, and Mathematics) TERHADAP KREATIVITAS PESERTA DIDIK
}

\author{
Indah Arsy ${ }^{1}$, Syamsulrizal ${ }^{2}$ \\ ${ }^{12}$ Univerwsitas Pendidikan Muhammadiyah Sorong \\ 1Indaharsy118@gmail.com, ${ }^{2}$ syamsulrizal05@gmail.com
}

\begin{abstract}
ABSTRAK
Penelitian ini mengkaji pengaruh penerapan metode STEAM terhadap keratifitas peserta didik. Metode yang diguanakan dalam penelitian ini yaitu menggunakan metode telaah pustaka. Metode telaah pustaka adalah kajian atas pembahasan suatu topik yang sudah ditulis oleh para peneliti atau ilmuan di dalam berbagai sumber. Sumber informasi tersebut dapat diperoleh melalui buku, jurnal, ebook, ataupun artikel ilmiah lainnya. Hasil yang diperoleh bahwa pembelajaran dengan menggunakan metode STEAM memiliki pengaruh terhadap kreatifitas peserta didik. Dengan adanya STEAM dalam pembelajaran sangat berguna dan bermanfaat, dapat diketahui bahwa tidak hanya aspek kognitif yang dikembangkan, pembelajaran STEAM juga dapat mengembangkan kreativitas peserta didik untuk menghadapi tantangan-tantangan dimasa mendatang Meskipun terdapat perbedaaan pendapat dari beberapa ahli namun metode STEAM dapat menjadi solusi pembelajaran bagi peserta didik dalam mengahadapi perkembagan teknologi yang dipadukan dengan ilmu pengetahuan.
\end{abstract}

Kata Kunci: STEAM, Kreatifitas, Peserta Didik

\begin{abstract}
This study examines the effect of the application of the STEAM method on the creativity of students. The method used in this research is to use the literature review method. The literature review method is a study of the discussion of a topic that has been written by researchers or scientists in various sources. Sources of this information can be obtained through books, journals, ebooks, or other scientific articles. The results obtained that learning using the STEAM method has an influence on the creativity of students. With the existence of STEAM in learning which is very useful and useful, it can be seen that not only cognitive aspects are developed, STEAM learning can also develop students' creativity to face future challenges. students in dealing with technological developments that are combined with science.
\end{abstract}

Keywords: STEAM, Creativity, Students

\section{PENDAHULUAN}

Perkembangan teknologi dasawarsa ini menujukan bahawa dunia semakin berkembang, begitu juga halnya dengan pendidikan. Dalam bidang pendidikan, tentu saja pengembangan kemampuan siswa dalam menguasai teknologi telah diupayakan pada setiap pembaruan kurikulum yang dilakukan pemerintah guna memperoleh generasi bangsa yang siap dan handal dalam menghadapi era globalisasi. Pembelajaran STEAM (Science, Technology, Engineering, Arts, and Mathematics) merupakan sebuah integrasi dari berbagai disiplin ilmu yaitu sains, teknologi, teknik, seni dan matematika yang berada dalam satu kesatuan pendekatan pembelajaran. mendefinisikan STEAM sebagai integrasi disipilin ilmu seni ke dalam kurikulum dan pembelajaran pada wilayah sains, teknologi, teknik dan matematika yang telah dikenal sebelumnya sebagai $(\text { STEM })^{(1)}$. STEAM merupakan meta disiplin ilmu yang mengintegrasikan sains, teknologi, teknik, seni dan matematika menjadi sebuah pendekatan terpadu yang dapat diimplementasikan dalam pembelajaran di sekolah.
STEAM sebagai sebuah pendekatan pembelajaran merupakan sarana bagi peserta didik untuk menciptakan ide/gagasan berbasis sains dan teknologi melalui kegiatan berpikir dan bereksplorasi dalam memecahkan masalah berdasarkan pada lima disiplin ilmu yang terintegrasi. Pemecahan masalah jika dilakukan berdasarkan beberapa disiplin ilmu, maka akan menghasilkan sebuah solusi yang sangat tepat, tidak hanya pemecahan masalah matematik namun berdasarkan konsep yang berhubungan dengan disipilin ilmu lain sehingga pemecahan masalah akan menjadi sangat menarik, efektif dan efisien.

Dalam pembaruan kurikulum 2013 yang telah ditetapkan pemerintah, peserta didik diharapkan akan mampu memiliki kemampuan hidup sebagai pribadi dan warga negara yang beriman, produktif, kreatif, inovatif, dan efektif serta mampu berkontribusi pada kehidupan bermasyarakat, berbangsa, bernegara dan peradaban dunia ${ }^{(2)}$. Harapan dan tujuan pendidikan pada kurikulum 2013 tersebut dapat dilaksanakan melalui pendekatan pembelajaran berbasis STEAM yang menawarkan pendidikan meta dispilin ilmu dalam mengembangkan kemampuan berpikir dan 
kreativitas dalam suatu memecahkan masalah. STEAM akan dapat memberikan kesempatan baru kepada peserta didik untuk melakukan proses pembelajaran desain secara langsung dan menghasilkan produk dengan kemampuan kreativitas dan pemecahan masalah yang baik. Kreativitas dan kemampuan berpikir menjadi dua aspek penting yang harus dimiliki peserta didik guna menghadapi era globalisasi yang semakin tinggi.

\section{METODE PENELITIAN}

Metode yang digunakan dalam penelitian ini adalah metode telaah pustaka. Metode telaah pustaka adalah kajian atas pembahasan suatu topik yang sudah ditulis oleh para peneliti atau ilmuan di dalam berbagai sumber. Sumber informasi tersebut dapat diperoleh melalui buku, jurnal, ebook, ataupun artikel ilmiah lainnya.

Langkah-langkah yang dilakukan dalam penelitian ini adalah: 1) mengumpulkan data mengenai STEAM terhadap kreativitas peserta didik di sekolah dasar; 2) menganalisis semua data yang telah diperoleh berdasarkan pemikiran penulis; dan 3) menyimpulkan hasil analisis telaah pustaka.

\section{PEMBAHASAN}

STEAM didefinisikan dengan cara yang berbeda oleh setiap para ahli. Dari berbagai definisi mengenai STEAM merujuk pada satu kesimpulan bahwa STEAM merupakan disiplin ilmu yang mengintegrasikan sains, teknologi, teknik, seni, dan matematika yang menjadi suatu pendekatan yang dapat diimplementasikan dalam suatu pembelajaran di sekolah.

Integrasi unsur seni dalam pembelajaran STEAM memberikan kesempatan kepada peserta didik untuk melatih kreativitasnya dalam proses pembelajaran. STEAM tidak hanya memuat aspek kognitif, namun memuat beberapa aspek lain yaitu afektif dan spikomotor yang dapat dikembangkan secara general oleh peserta didik dalam menghadapi era revolusi industri 4.0. kompleksitas abad 21 dewasa ini menuntut kemampuan dalam berbagai bidang dan pembelajaran berbasis STEAM dapat menjadi persiapan dan latihan menghadapi semuanya ${ }^{(3)}$.

Kemampuan kognitif dan kreativitas harus terus dikembangkan dalam berbagai bentuk salah satunya melalui pembelajaran yang menerapkan STEAM yang mengintegrasikan desain, kreativitas, dan inovasi pada disiplin ilmu sains, teknologi, teknik, seni, dan matematika sehingga dapat mengembangkan kemampuan-kemampuan yang dibutuhkan dalam menghadapi globalisasi dan perkembangan ilmu pengetahuan. sekolah dasar tingkat satuan pendidikan yang cocok untuk penerapan pembelajaran berbasis STEAM $^{(3)}$. Hal ini dikarenakan pada jenjang sekolah dasar mata pelajaran diajarkan secara tematik terintegrasi.

Pada jenjang sekolah dasar, setiap mata pelajaran diajarkan berdasarkan tema. Setiap tema dapat memuat beberapa kajian ilmu diantaranya matematika, IPA, IPS, bahasa Indonesia, SBDP, dan lain sebagainya sehingga pembelajaran berdasarkan tema dapat diimplementasikan dengan pembelajaran berbasis STEAM.

Kreativitas dapat dikembangkan melalui lingkungan yang mendukung di mana siswa merasa didorong untuk berpikir secara mandiri, melakukan eksplorasi dan permainan, pengamatan dan refleksi, dan pengajuan pertanyaan yang tidak biasa. Dari pembelajaran STEAM ini menunjukkan bahwa pembelajaran STEAM dapat mengembangkan kreativitas siswa atau sebagai sarana untuk meningkatkan keterampilan pemecahan masalah dunia nyata. STEAM juga menekankan pada integrasi domain keterampilan umum seperti keterampilan pengambilan perspektif, keterampilan kreatif dan pemecahan masalah, transfer pengetahuan lintas disiplin ilmu, dan/atau mendorong siswa untuk mengeksplorasi dan memberikan pengalaman dengan cara-cara baru. Pengembangan kreativitas di kelas lebih tergantung pada cara-cara di mana guru melaksanakan kegiatan dan jenis kegiatan yang digunakan di kelas. Guru memiliki perbedaan dalam konsepsi kreativitas dan keyakinan mereka dalam kemampuan untuk mendukung kreativitas siswa. Pembelajaran STEAM juga menyediakan ruang desain kreatif bagi para guru di berbagai bidang pembelajaran untuk berkolaborasi dalam mengembangkan kurikulum terintegrasi. Pembelajaran STEAM dalam skala sederhana dapat dirancang dan dilaksanakan oleh seorang guru yang inovatif, Pendidik STEAM dapat mengambil inspirasi dari pembelajaran berbasis proyek. STEAM melibatkan siswa dalam pembelajaran transformatif, yang didasarkan pada lima cara pengetahuan yang saling berhubungan: pengetahuan budaya, pengetahuan relasional, pengetahuan kritis, pengetahuan visioner dan etis, dan pengetahuan dalam tindakan.

STEAM juga merupakan salah satu pembelajaran kooperatif sebagai bagian dari pembelajaran kontruktivisme, dimana peserta didik akan membangun pengetahuan dan pemahamannya sendiri melalui proyek. Dengan pemberian proyek menuntut peserta didik untuk memahami materi yang sedang dipelajari sebagai sebuah pengetahuan, memanfaatkan teknologi yang sedang berkembang untuk membantu menemukan konsep, dan setiap tahapan STEAM yang terintegrasi pembelajaran berbasis proyek diharapkan dapat meningkatkan kreativitas pada setiap peserta didik. STEAM yang terintegrasi dengan pembelajaran berbasis proyek menempuh enam tahap, yaitu : a) pemberian pertanyaan esensial; b) penyusunan rencana proyek; c) penyusunan jadwal; d) monitoring kemajuan proyek; e) pengujian dan penilaian hasil; f) evaluasi pengalaman

Dengan adanya STEAM dalam pembelajaran sangat berguna dan bermanfaat, dapat diketahui bahwa tidak hanya aspek kognitif yang dikembangkan, pembelajaran STEAM juga dapat mengembangkan kreativitas peserta didik untuk menghadapi tantangantantangan dimasa mendatang. 


\section{KESIMPULAN}

Pembelajaran dengan menggunakan metode STEAM ini, peserta didik akan terlibat dalam berbagai disiplin ilmu secara bersamaan, mereka mempelajari berbagai hal serta perspektif yang berbeda dalam menyelesaikan masalah atau problem solving. Pendekatan ini mempersiapkan peserta didik untuk tantangan sejati dunia yang semakin kompleks. Pembelajaran menggunakan metode STEAM memiliki pengaruh terhadap kreatifitas peserta didik.

\section{DAFTAR PUSTAKA}

1. Buinicontro, J. K. (2018). Gathering STE(A)M: Policy, Curricular, And Programmatic Developments In Arts-Based Science, Technology, Engeneering, And Mathematics Education Introduction To Special Issue Of Art Education Policy Review: STEAM Focus. Art Education Policy Review Journal. Volume 119, 2018 - Issue 2.

2. Permendikbud. 2013. Kerangka Dasar dan Struktur Kurikulum Sekolah menengah Pertama/Madrasah Tswnawiyah No 68.

3. Wijaya, A.D., dkk. 2015. Implementasi Pembelajaran Berbasis STEAM (Science, Technology, Engineering, Art, Mathematics) Pada Kurikulum Indonesia. Proseding pada Seminar Nasional Fisika dan Aplikasinya. Universitas Padjadjaran Bandung. Sabtu 21 November 